\title{
Discourses about crack in the printed mass media
}

\section{Discursos sobre o crack na mídia de massa impressa}

\author{
Adriane ROSO \\ Moises ROMANINI ${ }^{2}$ \\ Fernanda dos Santos de MACEDO ${ }^{3}$ \\ Mônica ANGONESE ${ }^{3}$ \\ Alex Barcelos MONAIAR \\ Marilia Pinto BIANCHINI ${ }^{4}$
}

\begin{abstract}
This work aims to present the results of the quantitative part of the research project entitled "Ideology, production of subjectivities and drugs: media discourse on crack in the (post)modern culture". The methodology consisted of an analysis of the symbolic forms that refer to the crack published in two newspapers of general circulation within the central region of the state of Rio Grande do Sul, Brazil. The descriptive statistical analysis of data was performed using the SPSS v.17 software. The results suggest that these newspapers treated the use of crack as a "police matter", linking it directly to violence. However, there was a lack of in-depth discussions regarding the causes and consequences of this phenomenon.
\end{abstract}

Uniterms: Crack (drugs); Newspaper; Social psychology.

\section{Resumo}

Este trabalho tem como objetivo apresentar os resultados da parte quantitativa do projeto de pesquisa intitulado "Ideologia, produção de subjetividades e drogas: discursos midiáticos sobre o crack na cultura (pós)-moderna". A metodologia consistiu em uma análise das formas simbólicas que se referem ao crack veiculadas em dois jornais de circulação geral na região central do estado do Rio Grande do Sul, Brasil. A análise estatística descritiva dos dados foi realizada com auxílio do Software IBM SPSS Statistics 17. Os resultados sugerem que esses jornais têm tratado o uso de crack como um "caso de polícia", associando-o diretamente à violência. Contudo, constata-se uma ausência de discussões aprofundadas sobre as causas e as consequências de tal fenômeno.

Unitermos: Crack (drogas); Jornais; Psicologia social.

"Drugs are an emphasis, neither demonic nor paradise: they are chemical agents that amplify the phenomena, the micro/macro processes" (Rotelli, 1992, p.67). Since prehistoric times, these different "chemical agents" have been used for a wide range of purposes, extending from recreational use, with pleasurable

\section{$\mathbf{V} \mathbf{V}$}

1 Universidade Federal de Santa Maria, Programa de Pós-Graduação em Psicologia. R. Floriano Peixoto, 1750, Sala 321, 30 Andar, Sala 321, Centro, 97530-270, Santa Maria, RS, Brasil. Correspondência para/Correspondence to: A. ROSO E-mail: <adrianeroso@gmail.com>.

2 Universidade Federal do Rio Grande do Sul, Programa de Pós-Graduação em Psicologia Social e Institucional. Porto Alegre, RS, Brasil.

3 Universidade Federal de Santa Maria, Curso de Psicologia. Santa Maria, RS, Brasil.

- Universidade Federal de Santa Maria, Residência Multiprofissional. Santa Maria, RS, Brasil. 
purposes, to the triggering of ecstatic mystical/religious states. Their use for healing purposes, whether in religious practices, or in the current medical and scientific context is also noteworthy (Bucher, 1992; Escohotado, 1997).

Crack, a drug that emerged in the United States in the late 1980s, as a form of smoked cocaine (Laranjeira, Jungerman \& Dunn, 1998), entered Brazil ten years later (Kessler \& Petchansky, 2008). In general, crack (and cocaine derivatives) is consumed by a small portion of the population (2.3\%), mainly in the South and Southeast regions. The consumption is more prevalent among youths and young adult males. The presentations for smoked use have important regional variations, with crack more prevalent in the South and Southeast, and paste in the North (Duailibi, Ribeiro \& Laranjeira, 2008).

Like other drugs, crack has also reached the smaller cities. According to the Centro Brasileiro de Informações Sobre Drogas Psicotrópicas (Carlini et al., 2006), the use of crack (along with marijuana and opiates) presented one of the highest rates of growth among the interviewees of the cities with more than 200,000 inhabitants in Southern Brazil. From 2001 to 2005, the use of crack went from 0.5 to 1.1 , behind marijuana (from 8.4 to 9.7), solvents (4 to 5.7) and opioids (1.2 to 2.7$)$.

It is not possible to say whether crack is more visible on the streets, in the daily life of people, or in the screen and print media. We believe that the ways in which some mass media convey news about the drug are inadequate. As stated by Deleuze (1992), in addition to it being clear that we do not know what to do with the drug (or with the users), it is also clear that we don't know how to talk about it in another way.

This study intends to focus on the print media, taking crack as the object of study. In choosing the written media, we do not intend to disqualify the power of influence of the other means of mass communication, but to put it under the analysis spotlight. According to van Dijk (2008), within all the forms of printed text, those of the means of mass communication are the most penetrating, being the most influential, if judged according to the criterion of power based on the number of receivers. With this, the mediatic discourse, 456 especially the journalistic one, has a prominent role in public communication. Through it, knowledge is acquired and, mainly, opinions formed. As a consequence of the great power of the print media, many guidelines for everyday life are put forward by the mediatic discourse and known only through it, and not through direct experience.

Realizing that people are increasingly using the internet in search of information, much of the written media has taken advantage of this medium to convey their material. This means that the print media is also present in the virtual field, i.e., it "has not disappeared or lost its importance, just expanded its scope of action". Even with a strong presence in the virtual field, its printed circulation has grown recently. According to the Instituto Verificador de Circulação in Brazil, the newspapers at the end of the first half of 2011 achieved an audited circulation of 4,435,581 copies, which equates to an average growth of $4.2 \%$ over the same period of the previous year (Associação Nacional de Jornais, 2011).

One of the first studies that focused on the media and its relationship with crack was that of Hartman and Gollub (1999), which showed that articles published in American newspapers about the "crack epidemic" were sensationalist, without scientific basis and contributed to divert the focus of the authorities from other more urgent social problems.

Crack, which existed before being emphasized by the print and screen media, became the agenda and "epidemic" at the time in which it was mediatized daily. What is being conveyed in the mass media naturally becomes part of the everyday life of people: crack as the drug of the criminal, as the demonic drug. This placement creates a dichotomy between the self and the other (the crack user). This is the worldly character of receptive activity (Thompson, 2007), in which the construction of social behavior - what is acceptable or not - becomes largely controlled and dictated by external agents. Here we enter the field of ideology, a field often designated as outmoded.

Nevertheless, we believe that with the advent of postmodernism, especially with globalization, it becomes necessary to consider ideology from a new perspective. If ideology could previously be thought of as a force of oppression of the macro-structure of the state, now operative ideology is more difficult to "grasp", 
to visualize. Thompson (2007) offers us an approach that illuminates the study of mass media and of ideology. He developed a way to analyze the media that is fundamentally ideological and cultural, that is, which is concerned not only with the significant character of the symbolic forms, but also with their social context. The importance is not just in what they mean, but how they make the meaning within a particular social context. The central point of his analysis is precisely the operators of domination of the mass media.

Through the media, the symbolic forms produced are able to circulate on an unprecedented scale, contributing to the production of subjectivities of people around the entire world. The wide circulation of messages conveyed by the media has caused the mass media to become an important factor in the transmission of ideology in modern societies. Thus, the ideological phenomena can become mass phenomena, i.e., phenomena that can reach a growing number of receivers. The media can then collaborate with the creation, establishment and maintenance of asymmetric relationships, relationships of domination (Thompson, 2007).

Based on "mediated quasi-interaction" (Thompson, 2007), the construction of symbolic forms has to do with the fabrication and constitution of our subjectivity. We are forced to face the challenge of reconstructing our 'way of being' daily, of constituting our subjectivity, and the major medias broker the production process of subjectivities, constructing reality and putting the discussion "agenda" into society (Roso \& Guareschi, 2007).

Thus, the mass media, when conveying symbolic forms (discourses) about drugs such as crack produce and/or reinforce certain subjectivities and certain ways of living. From this perspective, to highlight and/or interpret the discourses of the mass media towards the use/user of drugs is an important step toward comprehending the ideology underlying the mediatic discourses and the recognition of the kinds of subjectivities that are produced in the postmodern culture.

If the concept of ideology is out of fashion in social psychology, the concept of subjectivity and subjectification processes are considered to be more avant-garde. At present, we can not think about the issue of drugs in the media without talking about subjectification processes. As Bock (2009) said, it is important to think about the issue of communication when we study and comprehend the construction of subjectivity.

It is not enough just to criticize the discourse of the issuer, otherwise we would commit a common mistake which is to characterize the media as the only villain of all time, responsible for all violence, poverty and other evils. We need to go further and comprehend the processes of subjectivization and singularization that permeate the daily lives of people. To solely blame the media for producing such a representation is not seeing the crux of the situation. Consequently, "the specialists, the institutions, the public and the press reinforce each other and together drive the war against the drug problem, which essentially turns against the drug consumers" (Bastos, Mesquita \& Marques, 1998, p.256).

Globalization, which intensifies mixtures and pulverizes identities, also implies the production of standard profile kits according to each circle of the market, to be consumed by the subjectivities, regardless of the geographic, national, or cultural context. Fixed local identities disappear to make way for flexible globalized identities that change with the whim of the market movements and at the same speed (Rolnik, 1997). The way the drug and the crack user are broadcast in the media redoubles this anesthesia of affects and reinforces the illusion of identity. This is performed through, sometimes very apparent, sometimes veiled, ideological strategies. So that we can think of singularization alternatives, we must uncover the discourses that reinforce the relationships of domination, which create illusions and exhaust the possibilities of the subjects - who are desubjected by the war on drugs policy - of becoming people.

Perhaps one way to introduce a break in the traditional discourses (mediatic or otherwise) is to make the distinction clear between the drug user and the drug dealer, based on the new drug law (Law no 11.343/ 2006). According to the document "The user and the dealer in light of the new drug law", prepared by the Centro de Apoio Operacional Criminal (Brasil, 2009), the situation of user has not lost its unlawful character, because drug possession has not been legalized. 
Although it constitutes an unlawful act, its sui generis nature, makes it necessary to treat users with responsibility, seeing them as a drug addicts and not as criminals. Drugs seized for personal consumption do not constitute an offensive potential, because of the small quantity, there is no need to talk about offense, whether criminal or not. The new law does not punish the user or dependent person with deprivation of freedom, rather it aims at their social integration. It is noted that "drug quantity, alone, does not normally constitute a determinant criterion, with some exceptions (large quantities of packets). Hence the need to appraise not only one criterion (the quantity), but all those set in the Law" (Brasil, 2009, p.11).

In the context of drug dealing, the new law gave provides for stringent treatment for the drug dealer, with the severity of the law not being intended for the end point dealer, first offender, with a good previous record and that is not a member of a criminal organization (Brasil, 2009). Thus, the drug user and the drug dealer do not have the same place in the legislation and, in principle, should not have the same place in the mass media.

In this article we present part of an ongoing quantitative and qualitative study, entitled "Ideology, production of subjectivities and drugs: mediatic discourses regarding crack in the (post)modern culture". Through the use of simple descriptive statistics for the data analysis, the aim of the quantitative part of this project is to map the data treatment by the print media in relation to the "crack" theme, especially considering the form and content elements of the news articles. This constitutes an important step to guide the trajectories of the analysis of ideologies and the production of subjectivities (qualitative factors), which are already initiated here with the support of a social critic based on the perspectives of Critical Discourse Studies and French Discourse Analysis.

We want to emphasize that the aim of this study is not to conspire against the media and journalists. The idea is to contribute to the movement of critical reflection of this ideological apparatus. After all, it is acceptable that the media believes it is doing its best, however, those responsible for mediatic discourse should consider the possible consequences of their discourse on the receivers. For van Dijk (2008) “... the print discourse is, in principle and generally, public and, therefore, its writers can be held responsible for it"(p.73).

\section{Method}

The methodological choice was guided by the method and the results of the study conducted by Agência de Notícias dos Direitos da Infância (ANDI, News Agency for Children's Rights), in partnership with the National STD/AIDS Program of the Ministry of Health, entitled "Media and Drugs - the profile of the use and user in the Brazilian press", which deals with the treatment given to the subject of drug use by the major newspapers and magazines in circulation in the country (Brasil, 2005).

We map the symbolic forms that refer to crack in two high circulation newspapers of the state of Rio Grande do Sul (period $6^{\text {th }}$ July 2008 to $6^{\text {th }}$ November 2009). The collection was performed using the online editions and the print edition, when available. Regarding the period analyzed, we chose July 6, 2008 as it was at this time that the Zero Hora newspaper published a series called "The Crack Epidemic", which can be considered the beginning of the massive propagation of symbolic forms about crack in the state of Rio Grande do sul.

We selected all the material that mentioned the word crack and, in a second reading, chose only those texts that had crack as the important focus, i.e., material that addressed crack directly or in a relevant way. These newspaper articles were read carefully by all members of the project. A list was created a priori of issues addressed or neglected by the newspapers.

A third reading was carried out in threesome, supervised by the research coordinator. At the same time that we were carefully reading and appropriating the symbolic forms, the questions were turned into twenty (20) variables, designed as follows: a) Form (source section, cover, day of week, level of approach, scope, size of the symbolic form, type of text); b) Content (image, image type, main actors, secondary actors, themes, drugs cited, consequences, expressions to denote a person who is a drug user, causes, solutions, age group and gender of the user). The list of variables was organized using the Statistical Package for the Social Sciences, version 17 software and simple descriptive statistics were used for the data analysis. 
With the statistical data in hand, we sought to draw connections with the results of the study cited at the beginning of the method "Media and Drugs - the profile of the use and user on the Brazilian press" (Brasil, 2005). Furthermore, we created some theoretical speculations based on studies that performed the process of interpretation of media productions from a critique of the social, aiming "to discover the unspoken, the hidden, and the possible meanings that are found behind the game of appearances" (Charaudeau, 2009, p.29). We included Critical Discourse Studies in this perspective (van Dijk, 2008; Thompson, 2007) and French Discourse Analysis (Charaudeau, 2009).

\section{Results and Discussion}

During the twelve months of the study, there were a total of 314 daily published editions, and a total number of 138 texts on crack (an approximate mean of 0.44 texts on crack per day). That is, in the period analyzed, both newspapers published some note or story that involved, directly or indirectly, issues relating to the drug crack (one text about crack approximately every two days), with a mean of 0.24 articles for newspaper $A$ and 0.20 for newspaper B. Thus, the sample consisted of 138 journalistic texts that directly involved crack, and, of these, 76 (55.1\%) were broadcast by vehicle $A$ and 62 (44.9\%) by vehicle B.

From the 138 newspaper articles, it was possible to statistically describe each variable related to the aims of our study. The analysis of the first variable - Day of the Week-showed us that the greatest number of texts were published on Friday (21.0\%) and the fewest on Sunday (1.4\%). Seventeen percent (17.4\%) of the news stories were published on the front covers of the newspapers 5 .

Regarding the section, it was observed that the majority (63.8\%) did not have a specific section. The Political section was more frequent (18.1\%), followed by the Readers Letters/Opinions (8\%) and the Summary (8\%). While there was no specific section, it was found in the texts analyzed, as well as in other studies
(Vedovatto, 2010; Brasil, 2005; Reinarman \& Levine, 2004), that the newspapers studied seem to treat drugs as an issue linked to the legal-judicial and medicalpsychiatric fields, being based exclusively on biomedical solutions-cures, a typical construction of the antidrug discourse.

It is worth remembering that the distribution of material into divisions (sections) is important, from the perspective of the analysis of mediatic discourse, as this constitutes the thematic configuration of the public space constructed by the media (Charadeau, 2009). Thus, the expressive quantitative data regarding the specified section (63.8\%), can serve as an indication that the media is not yet prepared to also handle/approach the subject from different perspectives (such as a health matter, or an element of history, etc.). It seems that there is a tendency to reproduce North American antidrug models and discourses, as already highlighted by Reinarman and Levine (2004) in another study, situating the drug as a police matter or a generic fact.

We identified four types of text, with Reports presenting the highest frequency (83.3\%), followed by Articles, with 11 texts (8.0\%), Interviews, with 4 (2.9\%), and Advertising and Others with 2 each (4.3\% each). These results are similar to the data of the study "Media and Drugs" (Brasil, 2005), which found a space of nearly $10.0 \%$ for the opinion, article, column and interview texts, and the vast majority (over 90.0\%) characterized as reports.

Approximately half of the texts contained images in the body of the text (41.3\%), and some of these had more than one image. Images of users (adults, children and/or adolescents) were those that appeared most (17.3\%), followed by images of crack/rocks (8.0\%). The remaining images and their frequency were: professionals/experts/authorities (5.0\%), police action/ seizure (2.9\%), family members $(0.7 \%)$, treatment in health institutions (0.7\%), and others (5.8\%).

Barroso (2006) highlighted the important and constant influence of images on people. According to the author, images guide the identification of the subject and, in this way, the constitution of the self.

$\boldsymbol{v} \nabla \boldsymbol{v}$

s This data refers only to vehicle "A", for which there was access to the printed version. As access to vehicle "B" was online, it was not possible to identify whether the respective texts were cover stories. 
Therefore it is crucial to think about how the images conveyed in the medias analyzed can be seen as influential in identifying the subjects. We noted that they were not aiming for the readers to identify themselves as wanting to be the same as the portrayed user. However, they may serve to constitute a model of non-identification. This is corroborated when one considers the dissemination of images as objects of manipulation or as a strategy of action.

In the texts analyzed the main actors most identified were the patients/users (25.4\%). Other actors highlighted were: Police/Military Police/Police Departments in 24 texts (17.4\%); Government Institutions in 21 (15.2\%); and the Drug Dealer in 18 (13.0\%).

The preponderance of the presence of the police as one of the main actors in the field shows that the media, as one of the ideological apparatus of the state (Althusser, 2001), believes that the "problem" of drugs requires repression, i.e., it works through the use of moral, psychological or physical force to suppress resistance or opposition. Therefore, the relationship between drug users and the repressive apparatus is shown asymmetrically, causing domination and not a healthy social commitment, i.e., in the majority of cases it does not seem to have acceptance, dialog and respect, but exclusion and fear of the other (the drug user) through the ideology of repression.

Here it is worth performing a reflection in relation to the players, based on the theories of Charaudeau (2009). He emphasizes that the actors to whom the media"gives the priority word are not always those elected, specialists or citizens likely to have certain social visibility" (p.192). The elected are those who represent the political institution and, consequently, the rhetoric they use is jargon characteristic of the politicians.

In our study, the elected were included in Government Institutions (15.2\%). Specialists do not appear as major actors, although we may consider them representatives of knowledge, seemingly unconnected to power relationships. They are included with the secondary actors; their statements and explanations are quite significant in the material analyzed, being represented by psychiatrists, psychologists and other healthcare professionals. Charaudeau (2009) alerts us to the fact that, when specialists are asked to give an opinion," "they know they should speak in a certain way and, simultaneously, show themselves to be "good specialists". Furthermore, the media does not invite whatever specialist" (p.194).

The citizen actor (represented in the Patients/ Users variable - 25.4\%), when present on the media, essentially appeared as two figures: That of the victim or complainant citizen, or that of the witness citizen (Charaudeau, 2009). The first figure, as an anonymous minority, only becomes interesting if they have suffered, have been victims of social injustice, or if they claim compensation. We noted, in a preliminary analysis, that this figure is the most recurrent in the analyzed texts: the crack users (actually the crack addicts) are victims of dependence and expressed their sorrow and despair. The second figure, the witness, "are faceless beings, individuals with no personality, no affection, no opinions, without another identity except that of the witness" (Charadeau, 2009, p.195). Their testimonies serve to authenticate the facts or comments broadcast in news stories.

The next variable that we explore here refers to the central theme. It was found that the most frequent themes in the material were: Repression/Combat (28.3\%), Relationships with Violence (15.2\%), Treatment (10.1\%) and Growing Consumption. The Campaigns theme appeared in eight texts (5.8\%) and Prevention in $\operatorname{six}(4.3 \%)$.

We can draw a parallel with the study "Media and Drugs - the profile of the use and user in the Brazilian press" (Brasil, 2005), where the main theme was "Relationships with violence", with a percentage of $27.5 \%$, with this representing the highest frequency in the subjects analyzed. This shows that not only are some protagonists privileged, but so are some themes.

Unfortunately, to establish as a priority theme "Relationships with violence", the media eventually establish a cause and effect relationship between drug use and crime rates. Although the use of crack can generate disruptions in social bonds, often these disruptions were already installed before the addiction, i.e., there is no intrinsic and deterministic relationship between crack and violence; there are, however, many factors that contribute to the manufacture and potentiation of certain types of relationships. The 
illegality of the substance being one of these. As Vedovatto (2010) reminds us, the prevention campaigns "demonize" the drug user to construct an image of the "junkie" who is responsible for all the ills of society.

Regarding the type of Drugs, in 97 of the texts crack is the only drug mentioned, representing $70.3 \%$. In other texts, crack appears especially associated with cocaine (11-8.0\%), with marijuana (4 - 2.9\%) and with alcohol (3-2.2\%). Crack is also associated with the combination of drugs: marijuana and cocaine (8-5.8\%), alcohol, marijuana and cocaine (5 to 3.6\%), and alcohol and cocaine (2 to $1.4 \%$ ).

To present other concerns beside the seizure of crack can lead the reader to associate the use of crack with the progression to the use of other drugs, creating/ reinforcing the idea that the use of one drug necessarily and naturally leads to the use of another. The danger of this association may be the expansion of the social fear facing the user: the more drugs used, the more dangerous it can become.

The expressions used by the newspapers to refer to people who consume illicit drugs (crack in this case) were: user (36 - 26.1\%); addict (15 - 10.9\%); dependent (12 - 8.7\%); victim (4 - 2.9\%); junkie (2 - 1.4\%). Excluding the expression "drunk", the data encountered are similar to many of the results found in the study "Media and Drugs - the profile of the use and user in the Brazilian press" (Brasil, 2005): user (7.7\%), dependent (7.1\%), addict (5.4\%), and junkie (4.7\%).

The use of some expressions to refer to people who use drugs may be discriminatory. Vedovatto (2010, p.163) reminds us that also in the health context:

We made that mistake when creating labels using technical terms "addicts", "chemical dependents", or even the commonsense terms: "junkie", "cannabis user", "crack user", in which we use a nomenclature based on the forms of use of a certain substance or based on the substance itself, taking from the subject/ individual their main essence of being human, of being a person.

The use of different expressions leads us to argue that we need to think about what ways could be employed to refer to people who use drugs without reinforcing discriminatory relationships that produce the distancing of these people from the healthcare services and the spaces of social and political participation. In drafting the Integral Care to Users of
Alcohol and Other Drugs Policy the term "user" is widely employed, however our experience in Psychosocial Care Centers leads us to question the use of even this term because"service users" are often confused with "product users". We still have no alternatives to this impasse, however, we believe it deserves further attention.

In the majority of the material (114 to $82.6 \%$ ) the causes of crack use were not presented. When they were present, they were the most varied, with no single one of them highlighted: Drugs per se (7 - 5.1\%); Failures and lack of services (4 - 2.9\%), Lack of information (3-2.2\%) and Sociability (desire to participate in the group) (2 - 1.4\%). In the study cited above, 'Drugs per se' (30.8\%) and 'Sociability' (13.8\%) appear as the most cited causes of drug use (Brasil, 2005).

However, the high rate (82.6\%) of texts that did not address the causes of crack use draws our attention. In the material analyzed, the subjects and the phenomenon of drugs were not presented in their sociocultural context. Again, Vedovatto (2010) helps us understand the omission of the causes from the texts, when he states that we observe that mediatic pieces, whether advertising or informative,

...sell, in the public sphere, a weak Subject, with low autonomy, impoverished and with a thoughtless attitude due to making use of a substance in an uncontrolled way, which destroys families, social life and working life, generalizing the fact as if all use will lead to destruction, breakdown of moral and ethical values and even to death (p.162).

Given that the characteristics of users are placed and accepted in common sense (and often in the discourse called "scientific"), what is the meaning of presenting and discussing the structural causes of the problem? It seems to be easier to keep blaming the users for their "addiction" and for the social problems, such as increased crime rates.

Regarding the consequences of crack use, 44 texts (31.9\%) did not address this issue. The variables thatweremostevidentare:Delinquency/crime (37 - 26.8\%), deprivation of liberty $(11-8 \%)$, health problems ( $8-5.8 \%)$ and therapy (8 - 5.8\%). Again the theme of violence emerges as a major factor, now as a consequence of crack use. As Minayo (2003) reminds us, it is the society itself that becomes "drugged" with the "drugs", creating its toxicomania, seeking escape from its deeper socio- 
structural problems. Thus, "one gets the impression that nothing else happens in society except for the drug, the violence and its consequences" (p.20).

Of the texts analyzed, half did not propose solutions to the problem presented. Of the texts that did, 36 (33\%) presented more than one solution. The solutions that stood out and their frequencies were: Hospitalization (18 - 13\%); Treatment (10 - 7.2\%); Policy for the sector (7 - 5.1\%) and More repression (7 - 5.1\%).

Although Hospitalization appeared as the more proposed solution, the health issue was rarely addressed, while the Treatment (10.1\%) and Prevention (4.3\%) themes came behind Repression/Combat (28\%) and Relationships with violence (15.2\%). Another important point is that hospitalization is a service of high complexity, in the sense of the levels of healthcare, and its demand should be below promotion and prevention, and when increasing this demand for hospitalization a force arises counter to that recommended of the National Health Service (SUS), in which the primary levels should have the highest investment.

Vedovatto (2010) highlights the need to end the fallacy that only the processes of long-term hospitalization, as one of the solutions to the issue of the drug problem, will provide benefits for the subjects. According to the author, "we must recognize that there are numerous alternatives to the question of treatment and prevention and that people have the right to choose the method that best meets their needs" (p.165).

Also in relation to the solutions, we noted that in the formulation of public policies aimed at the issue of drugs, various social actors are called upon to contribute: police, lawyers, physicians, psychologists, sociologists, and religious leaders, among others. However, the target audience is rarely called upon to participate in such constructions: drug users are not considered as "sources" that can contribute to improving the policies that address their needs. We realize that, in general, scientists occupy the position of spokespeople, of translators of knowledge dominated by a scientific language. However, instead of being just translators, it would be important to make a move in pursuit of traditionally disqualified discourses - that of the drug user being an example - considering that there is knowledge located outside the official sphere of 462 science, knowledge acquired in quotidian political practices, in the pursuit of life, which defies the order of official knowledge (Hüning \& Guareschi, 2008).

Crack certainly produces effects on the central nervous system, making dialogue difficult between healthcare professionals and the person who makes use of the substance. However, we believe that this dialogue is possible. We often lack professional resources (in the field of affection and also materials) to find appropriate ways to bring the user into dialogue with the service. This difficulty is not just related to people who use drugs. Just as we "overcame" the barriers to access a psychotic patient (using art, for example), we believe in the possibility of creating singular therapeutic projects and alternative forms of treatment, such as through conversation groups, and discussions of films about drugs, etc.

Regarding the level of approach to the theme, the majority can be classified as Factual (56.5\%). In 22 (15.9\%) the level of approach was Explanatory Contextual, in 21 (15.2\%) it was Contextual, in 7 (5.1\%) it was Evaluative, and in 10 (7.2\%) it was Propositional. It should be noted that the vast majority of the documents were characterized as being reports with factual approaches. This finding, coupled with the predominance of the crack-crime dyad and the concealment of causes, of solutions for the use, and of prevention, may suggest a preference, on behalf of the newspapers, to transmit a concept formed about crack and its users, rather than provide the readers with diverse information that would promote questioning so that the readers themselves could construct their opinions.

In the study "Media and Drugs - the profile of the use and user in the Brazilian press" (Brasil, 2005), the contextual level of approach had a higher frequency than the factual level. However, approximately $89 \%$ of the texts "did not propose a more detailed contextualization, such as presenting a historical and anthropological dimension for drug consumption, nor did they offer ideas, solutions or proposals" (Brasil, 2005, p.63). Therefore, the high rate of factual level material is related to the types of texts published (the vast majority were of the "report"type, at the expense of text such as articles and columns, fostering a more in-depth view of the theme) and the negligible number of texts that suggest an analysis of the causes, consequences and solutions for the problem. Therefore, 
... a whole series of structural problems that are at the origin of the difficulties and existential anguish suffered by large sections of the population are silenced by the difficulty of finding a language with which to develop and identify the root causes of their quotidian ailments. The drug - a fundamental part of a broader framework of "securitary discourses" through simple and compelling stereotypes, offers a means of escape and practice that, in addition to leaving the system that is the basis for all these conflicts and problems (including that of drugs) untouched, hinders the adoption of both political and technical measures for solving these problems (Romani, 2003, p.39).

Half of the material dealt with the local context (50.0\%), being followed by the regional (35.5\%), the national (13.8\%) and the international context (0.7\%).

Regarding the age group, in $41.3 \%$ of the texts there was no specification of any generational age and, when there was, youths were the most mentioned (28.3\%). Regarding gender, in $40.6 \%$ of the texts the gender of the user was not identified. Men were the focus in 43 (31.2\%) of the texts and women appeared in $14(10.1 \%)$ of them. Men and women appeared together in 25 texts (18.1\%).

The identification and definition by the media of public problems not only affect the mass audience, but also the public policymakers (Cook, 1997). We believe that the construction by the media of the crack epidemic influences not only how we react as individuals, but also how we react as a politically organized community.

The focus of the journalistic symbolic forms ends up being the drug again, reinforcing what Rotelli (1992) highlighted:

The problem faced (and always in a wrong way) is that of the drug of not that of drug dependence. The problem of drug dependence is never discussed, it is never interesting to hear the opinion of drug addicts. What is of interest is the drug phenomenon, to regulate it, and not the confrontation with the singular stories (p.68).

Why, for example, do these media not address the causes of drug use or emphasize the prevention of crack use? We think that perhaps they are not investing in the training of those who write the news story, which in turn can lead to the reproduction and maintenance of the negative stereotype of the crack user. The user provides a "scapegoat" for all the criminal problems in our society. "If the media is not limited to being impartial, only informing, it can take advantage and position itself for what seems to be more interesting and profitable, and this is ideological" (Felippe et al., 2004, p.2).

It is important to note the absences in the mediatic discourses. Take the case of AIDS: considering that a significant part of the national studies found that the consumption of the substance was responsible for the increase in risk for these infections, either due to the high number of partners and sex without protection, or due to the exchange of sex for crack or money to buy the substance (Duailibi et al. 2008), why do the texts not discuss questions related to HIV/Aids and harm reduction? Furthermore, by not discussing the reasons that drive the individual to use the drug nor proposing solutions, and the other "discursive absences" identified in the discussion, the possibility of thinking about this issue as something to be tackled globally is excluded.

Finally, it is worth emphasizing that the reprehension may increasingly hinder the social reinsertion of the users. Funds need to be distributed to create beds aimed at detoxification, however, financial investment in the training of the outpatient services (such as the Psychosocial Care Centers), and policies for valuing life are equally indispensable. The support of the community, without prejudice and stigmatization towards the user, is essential, however, these notions are difficult to disentangle because, as indicated by van Dijk (2008), the less conscious the representations, the easier it is to legitimize the dominant ethnic ideologies.

\section{Final Considerations}

The results of this study show an omission on behalf of the media in the discussion about the causes, and an emphasis on the issue of violence, being consonant with the study conducted by ANDI (News Agency for Children's Rights), in partnership with the National STD/AIDS Program of the Ministry of Health. The material regarding crack rarely extrapolate the personal histories and the biases of the violence, which weakens the contents that would lead to a greater 
contextualization of the issue in its various spheres and impairs the possibilities to expand the debate.

The study indicated the important elements in the mediatic discourses as: (a) emphasis on repression and on the fight against drugs; (b) a marked association of crack with violence; (c) opacity of women; and (d) a high-index of report type texts, of the factual level, which may indicate the reason why so many texts do not discuss causes and solutions.

We believe that these elements can support reflections that construct discursive [qualitative] analyses of the symbolic forms that refer to crack in the written media in focus, a movement that has already begun. This movement is sustained by the certainty that the media not only records and reproduces the reality, but creates it. In the case of the symbolic forms related to crack, it is assumed that the written news cause 'distorted' views on the theme to be maintained, when they establish a causal relationship between violence and crack use, restricting themselves, in most cases, to presenting "facts", without presenting any deeper discussion on the causes and consequences of the phenomenon. Thus, if the legal function of the media is to critically inform and educate citizens, the challenge that lies before the mainstream media in this process is to provide society with objective and straightforward information, which contributes to its reflection.

\section{References}

Althusser, L. (2001). Aparelhos ideológicos de estado. Rio de Janeiro: Graal.

Associação Nacional de Jornais. (2011). Relatório de atividades e de liberdade de imprensa: agosto de 2010 a julho de 2011. Recuperado em abril 3, 2012, disponível em <http:// www. anj.org.br/programas-e-acoes/relatorios/relatoriosde-atividades/RELATORIO\%20DE\%20ATIVIDADES \%202010-2011.pdf>.

Barroso, S. F. (2006). O uso da imagem pela mídia e sua repercussão na subjetividade contemporânea. Psicologia em Revista, 12(19), 92-97. Recuperado em junho 2, 2011, disponível em <http://pepsic.bvsalud.org/scielo. php? script=sci_issuetoc\&pid=1677-116820060001\& lng $=p t \& n r m=i s o>$.

Bastos, F. I., Mesquita, F., \& Marques, L. F. (Orgs.). (1998). Troca de seringas: drogas e Aids: ciência, debate e saúde pública. Brasília: Ministério da Saúde.

Bock, A. M. B. (2009). Seminário nacional mídia e psicologia: produção de subjetividade e coletividade. In Conselho Federal de Psicologia. Mídia e psicologia: produção de subjetividade e coletividade (2a ed., pp.19-20). Brasília: Conselho Federal de Psicologia.

Brasil. Ministério da Saúde. (2005). Mídia e drogas: o perfil do uso e do usuário na imprensa brasileira. Brasília: ANDI.

Brasil. Procuradoria Geral de Justiça do Ministério Público do Estado do Pará. (2009). O usuário e o traficante à luz da nova lei de drogas. Belém: Ministério Público do Estado. Recuperado em abril 2, 2012, disponível em <http://mp. pe.gov.br/uploads/_yGBJXSfXGy8YINWjNrc2A/ fwo0kip5NMrco-0bb7PK0A/Usuario_e_traficante_ de_drogas.PDF>.

Bucher, R. (1992). Drogas edrogadição no Brasil. Porto Alegre: Artes Médicas.

Carlini, E. A. (Superv.). (2006). II Levantamento domiciliar sobre o uso de drogas psicotrópicas no Brasil : estudo envolvendo as 108 maiores cidades do país: 2005 - São Paulo : CEBRID - Centro Brasileiro de Informação sobre Drogas Psicotrópicas. Recuperado em setembro 5 , 2013, disponível em <http://200.144.91.102/sitenovo/ conteudo. aspx?cd=644>.

Charaudeau, P. (2009). Discurso das mídias. São Paulo: Contexto.

Cook, T. (1997). News coverage of AIDS. In P. Norris (Ed.). Politics and the press: The news media and their influences. London: Lynne Rienner.

Deleuze, G. (1992). Duas questões. In H. Daniel \& J. F. Costa. Saúdeloucura (n.3, 2a ed., pp.63-66). São Paulo: Hucitec.

Duailibi, L. B., Ribeiro, M., \& Laranjeira, R. (2008). Perfil dos usuários de cocaína e crack no Brasil. Saúde Pública, 24(4), 545-557.

Escohotado, A. (1997). O livro das drogas: usos e abusos, desafios e preconceitos. São Paulo: Dynamis.

Felippe, F. M. L., Friedman R., Alves, B. S., Cibeira, G. R., Surita, L. E., \&Tesche, C. (2004). Obesidade e mídia: o lado sutil da informação. Revista Acadêmica do Grupo Comunicacional de São Bernardo, 1(2), 166-171.

Hartman, D. M., \& Gollub, A. (1999). The social construction of the crack epidemic in the print media. Journal Psychoactive Drugs, 131(4), 423-33.

Hüning, S. M., \& Guareschi, N. M. F. (2008). Para inventar o que as teorias não ensinam. In N. M. F. Guareschi (Coord.), Olhar vidas: a fotografia em uma pesquisa-intervenção (pp.11-14). Porto Alegre: Zouk.

Kessler, F., \& Petchansky, F. (2008). Uma visão psiquiátrica sobre o fenômeno do crack na atualidade. Revista de Psiquiatria, 30(2), 96-98.

Laranjeira, R., Jungerman, F., \& Dunn, J. (1998). Drogas: maconha, cocaína e crack ( $2^{\mathrm{a}}$ ed.). São Paulo: Contexto.

Minayo, M. C. S. (2003). Prefácio: sobre a toxicomania da sociedade. In M. Baptista, M. S. Cruz \& R. Matias (Orgs.), Drogas e pós-modernidade: faces de um tema proscrito (Vol. 2, pp.13-29). Rio de Janeiro: EdUERJ.

Reinarman, C., \& Levine, H. G. (2004). Crack in the rearview mirror: Desconstruting drug war mythology. Social Justice, 31(1-2), 182-199. 
Rolnik, S. (1997). Psicologia: subjetividade, ética e cultura. In A. E. Silva, C. A. Neves \& C. Rauter (Orgs.), Subjetividade: questões contemporâneas (pp.13-21). São Paulo: Hucitec.

Romani, O. (2003). Informação sobre drogas: ações, valores e orientações. In M. Baptista, M. S. Cruz \& R. Matias (Orgs.), Drogas e pós-modernidade: faces de um tema proscrito (Vol. 2, pp.33-42). Rio de Janeiro: EdUERJ.

Roso, A., \& Guareschi, P. A. (2007). Megagrupos midiáticos e poder: construção de subjetividades narcisistas. Política \& Trabalho, 26(1), 37-54.

Rotelli, F. (1992). Onde está o senhor? In H. Daniel \& J. F. Costa. Saúdeloucura (n.3, 2a ed., pp.66-76). São Paulo: Hucitec.
Thompson, J. B. (2007). Ideologia e cultura moderna: teoria social crítica na era dos meios de comunicação de massa (7a ed.). Petrópolis: Vozes.

Van Dijk, T. A. (2008). Discurso e poder. São Paulo: Contexto.

Vedovatto, S. M. A. (2010). Contrapondo o discurso midiático sobre drogas: nem tão feios, nem tão sujos, nem tão malvados: pessoas de bem também usam drogas! In L. M. B. Santos (Org.), Outras palavras sobreo cuidado de pessoas que usam drogas (pp.1-10). Porto Alegre: Conselho Regional de Psicologia do Rio Grande do Sul.

Received on: 8/9/2011

Final version on: 11/4/2012

Approved on: 7/5/2012 